Original Articles

\title{
Platelet Count Response to Helicobacter pylori Eradication in Iranian Patients with Idiopathic Thrombocytopenic Purpura
}

Mehrdad Payandeh ${ }^{1,2}$, Nasrollah Sohrabi ${ }^{1}$, Mohammad Erfan Zare ${ }^{2,3}$, Atefeh Nasir Kansestani ${ }^{2,3}$, Amir Hossein Hashemian $^{4}$

${ }^{1}$ Department of Medical Laboratory Sciences, Paramedicine Faculty, Kermanshah University of Medical Sciences, Kermanshah, Iran.

${ }^{2}$ Medical Biology Research Center, Kermanshah University of Medical Sciences, Kermanshah, Iran.

${ }^{3}$ Student Research Committee, Kermanshah University of Medical Sciences, Kermanshah, Iran.

${ }^{4}$ Department of Biostatistics, Faculty of Public Health, Kermanshah University of Medical Sciences, Kermanshah, Iran.

Correspondence to: Mohammad Erfan Zare, BSC student of Medical Laboratory Sciences. Medical Biology Research Center, P.O.Box: 1568, Sorkheh Lizheh, Kermanshah University of Medical Sciences, Kermanshah, Iran. Tel: +98 831 4276473, Fax: +98 831 4276471. E-mail: mezarelab@yahoo.com

Competing interests: The authors have declared that no competing interests exist.

Published: August 10, 2012

Received: May 28, 2012

Accepted: July 24, 2012

Citation: Mediterr J Hematol Infect Dis 2012, 4(1): e2012056, DOI: 10.4084/MJHID.2012.056

This article is available from: http://www.mjhid.org/article/view/10555

This is an Open Access article distributed under the terms of the Creative Commons Attribution License (http://creativecommons.org/licenses/by/2.0), which permits unrestricted use, distribution, and reproduction in any medium, provided the original work is properly cited.

Abstract. Idiopathic thrombocytopenic purpura (ITP) is an autoimmune hematological disorder characterized by auto antibody-mediated platelet destruction. Although the main cause of ITP remains unclear, but its relationship with some infection was demonstrated. In recent years, many studies have demonstrated improvement of platelet counts in ITP patients after treating Helicobacter pylori infection. The aim of this study was to investigate the effects of $H$. pylori eradication on platelet count response in Iranian ITP patients.

A total of 26 patients diagnosed with both ITP and $H$. pylori infection. ITP were diagnosed whose platelet counts were less than $100 \times 10^{3} / \mu \mathrm{L}$. These patients were tested for $H$. pylori infection by Urea Breath Test and serum $H$. pylori antibody. All patients received triple therapy for 7 or 14 days to eradicate $H$. pylori infection. These patients followed for six months.

Prevalence of $\mathrm{H}$. pylori was 67.3\%. $\mathrm{H}$. pylori eradication achieved in $89.5 \%(26 / 29)$. Of the 26 patients, $15(57.7 \%)$ exhibited a complete response (CR) and $11(42.3 \%)$ were unresponsive. We did not find partial responders. There was a significant difference in the baseline platelet count of responders and non-responders patients $(p<0.001)$. All responders had platelet count $\geq 50 \times 10^{3} / \mu \mathrm{L}$ and all non-responders had platelet count $<50 \times 10^{3} / \mu \mathrm{L}$.

Results of this study revealed that eradication therapy of $\boldsymbol{H}$. pylori infection can improve platelet counts in ITP patients especially with mild thrombocytopenia and support routine detection and treatment of $\mathrm{H}$. pylori infection in ITP patients in populations with a high prevalence of this infection. 
Introduction. Helicobacter pylori (H.pylori) is the most common chronic pathogen that colonizes the human gastric mucosa. It has been recognized as the causative agent of chronic gastritis, gastro duodenal ulcers, adenocarcinoma and mucosa-associated lymphoid tissue lymphoma (MALT). ${ }^{1,2}$ The prevalence of H.pylori infection in geographic regions of the world is different. ${ }^{2}$ This rate in the most of the Asian countries such as Japan, South Korea and Iran is too high, but in Western countries is much lower. ${ }^{3-6}$ In recent years, several studies have proposed that H.pylori infection may be associated with some extra gastric disease especially hematological disorders such as iron deficiency anemia, pernicious anemia and idiopathic thrombocytopenic purpura (ITP) ${ }^{7-9}$

ITP is an autoimmune hematological disorder characterized by auto antibody-mediated platelet destruction. Although the main cause of ITP remains unclear, but its relationship with some infection was demonstrated. ${ }^{10-12}$ In 1998, Gassbarrini, for first time, observed increased platelet counts after H.pylori eradication in ITP patients. ${ }^{9}$ In recent years, many studies have demonstrated improvement of platelet counts in ITP patients after treating H.pylori infection. ${ }^{13-18}$ But in some studies, were observed no favorable effect on patients with ITP. ${ }^{19,20}$ The discrepancy might be due to different strains of H.pylori in these geographic regions. In this study we investigated the effects of H.pylori eradication on platelet counts in ITP patients in a teaching hospital in Kermanshah, west of Iran.

Material and Methods. In this retrospective study, between June 2009 and November 2010, 52 patients with ITP who attended the Taleghani hospital in Kermanshah, west of Iran, were evaluated. ITP was diagnosed according to the standard criteria and defined by thrombocytopenia (platelet counts $\leq 100 \times 10 \%{ }^{3}{ }^{21}$ Other causes of thrombocytopenia such as thrombocytopenia caused by drugs, pseudothrombocytopenia, hepatitis $\mathrm{C}$ virus infection, hepatitis B virus infection, human immunodeficiency virus infection and autoimmune disorders were excluded. The patients also were excluded if they had been received eradication therapy for H.pylori infection within 2 years or an antibiotic or proton pump inhibitor within the previous 4 weeks.

We used Urea Breath Test (UBT) and serum H.pylori antibody for diagnosis of H.pylori infection. ${ }^{22}$ All patients with H.pylori infection was treated with standard eradication therapy included amoxicillin 1000 $\mathrm{mg}$ twice daily, clarithromcin $500 \mathrm{mg}$ twice daily, and a proton pump inhibitor $40 \mathrm{mg}$ twice daily for 2 weeks. ${ }^{23}$ Eradication of H.pylori was evaluated two weeks after treating by the same tests which we used for diagnosis of H.pylori infection. Platelet counts were monitored every 2 weeks for the first 2 months, every month for the next 4 months after the end of treatment. Complete response (CR) was defined as a platelet count $\geq 100 \times 10^{3} / \mu \mathrm{L}$ at month 6 . Partial response (PR) was defined by a platelet increase of $\geq 30 \times 10^{3} / \mu \mathrm{L}$ and at least a doubling of the base line count at month 6 . No response (NR) was defined a platelet count $<30 \times 10^{3} / \mu \mathrm{L}$ or a count increase less than 2-times the baseline count after month $6 .^{21}$ According to declaration of Helsinki; we took consent from all patients before H.pylori eradication for remedy of their ITP disorders.

Differences of platelet count are expressed as the mean (SD) as appropriate. An ANOVA test was used for analysis of platelet differences in 3 groups (CR, PR and NR); the t-test was used to compare positive and negative response. A P-value of less than 0.05 was considered statistically significant. All statistical analysis were performed by using SPSS software version 16.0.

Results. Of 52 patients with ITP, H.pylori infection was found in $67.3 \%$ (35/52) of patients. Three patients with autoimmune disorders, two patients with HBV infection and one patient with $\mathrm{HCV}$ infection were excluded.Thus 29 patients were considered whom 26 (13 males, 13 females, mean age 38.2 years) achieved H.pylori eradication (89.6\%). After $H$ pylori eradication, CR was obtained in $57.7 \%(15 / 26)$ of patients $\left(\mathrm{CR}=\right.$ platelet count $\left.\geq 100 \times 10^{3} / \mu \mathrm{L}\right) ; 11$ patients (42.3) were unresponsive . No PR was found. (Table 1). There is a significant difference between the platelet counts of responders and non-responders $(p<0.001)$ (Table 2). All responders had platelet count $\geq 50 \times 10^{3} / \mu \mathrm{L}$ and all non-responders had platelet count $<50 \times 10^{3} / \mu \mathrm{L}$ (Table 1 and Figure 1).

Discussion. ITP is an autoimmune blood disorder in which platelet destruction is mediated by anti-platelet antibodies. $^{7-9}$ The mechanisms of anti-platelet antibodies development are still a little known. The association between ITP and some infections has been reported previously. ${ }^{10-12}$ For first time, Gasbarrini in 1998 proposed that H.pylori infection may be associated with ITP. ${ }^{9}$ In recent years, many studies have demonstrated improvement of platelet counts in ITP patients after treatment of H.pylori infection. ${ }^{13-18}$

In our study, the prevalence of H.pylori infection in ITP patients was $69.3 \%$. This rate similar to prevalence of H.pylori infection in the general population in Iran. ${ }^{5}$ These results also were comparable to those of previous studies which were done in Asian countries. ${ }^{6}$ 
Table 1. Clinical and platelet response characteristics by Patient

\begin{tabular}{|c|c|c|c|c|c|}
\hline \multicolumn{3}{|c|}{ Patient } & \multirow{2}{*}{$\begin{array}{c}\text { Baseline platelet } \\
\text { count } \times 10^{3} / \mu L\end{array}$} & \multirow{2}{*}{$\begin{array}{c}\text { Mount } 6 \text { platelet } \\
\text { count } \times 10^{3} / \mu L\end{array}$} & \multirow{2}{*}{$\begin{array}{c}\text { Response } \\
\text { status }\end{array}$} \\
\hline No & Sex & Age & & & \\
\hline 1 & $\mathrm{M}$ & 29 & 60 & 157 & CR \\
\hline 2 & $\mathrm{~F}$ & 28 & 84 & 196 & CR \\
\hline 3 & M & 34 & 73 & 164 & CR \\
\hline 4 & $\mathrm{~F}$ & 23 & 86 & 153 & CR \\
\hline 5 & M & 57 & 54 & 151 & CR \\
\hline 6 & M & 37 & 87 & 163 & CR \\
\hline 7 & $\mathrm{~F}$ & 32 & 96 & 183 & CR \\
\hline 8 & M & 17 & 78 & 145 & CR \\
\hline 9 & $\mathrm{~F}$ & 48 & 54 & 114 & $\mathrm{CR}$ \\
\hline 10 & M & 38 & 80 & 145 & CR \\
\hline 11 & $\mathrm{~F}$ & 19 & 75 & 111 & CR \\
\hline 12 & $\mathrm{~F}$ & 32 & 96 & 130 & CR \\
\hline 13 & $\mathrm{~F}$ & 42 & 80 & 130 & CR \\
\hline 14 & $\mathrm{~F}$ & 27 & 50 & 123 & CR \\
\hline 15 & M & 43 & 68 & 134 & CR \\
\hline 16 & $\mathrm{M}$ & 54 & 43 & 57 & NR \\
\hline 17 & $\mathrm{M}$ & 43 & 29 & 38 & NR \\
\hline 18 & $\mathrm{M}$ & 37 & 22 & 26 & NR \\
\hline 19 & M & 33 & 35 & 49 & NR \\
\hline 20 & $\mathrm{~F}$ & 33 & 38 & 48 & NR \\
\hline 21 & $\mathrm{~F}$ & 27 & 30 & 42 & NR \\
\hline 22 & $\mathrm{~F}$ & 65 & 33 & 52 & NR \\
\hline 23 & $\mathrm{M}$ & 71 & 40 & 49 & NR \\
\hline 24 & M & 19 & 48 & 61 & NR \\
\hline 25 & $\mathrm{~F}$ & 38 & 29 & 37 & NR \\
\hline 26 & $\mathrm{~F}$ & 67 & 39 & 48 & NR \\
\hline
\end{tabular}

Table 2. Differences of platelet according to outcome groups

\begin{tabular}{|c|c|c|c|c|c|c|}
\hline$\overline{\text { Outcome }}$ & $\mathbf{N}(\%)$ & Median & Minimum & Maximum & Mean SD & P-Value \\
\hline No response & $11(42.3)$ & 10000 & 4000 & 19000 & $11000+/-3974.9$ & $<0.001$ \\
\hline $\begin{array}{l}\text { Complete response } \\
\text { Total }\end{array}$ & $\begin{array}{l}15(57.3) \\
26(100)\end{array}$ & $\begin{array}{l}67000 \\
43000\end{array}$ & $\begin{array}{r}34000 \\
4000\end{array}$ & $\begin{array}{l}112000 \\
112000\end{array}$ & $\begin{array}{c}79917+/-20042.9 \\
6900021851.8\end{array}$ & \\
\hline
\end{tabular}

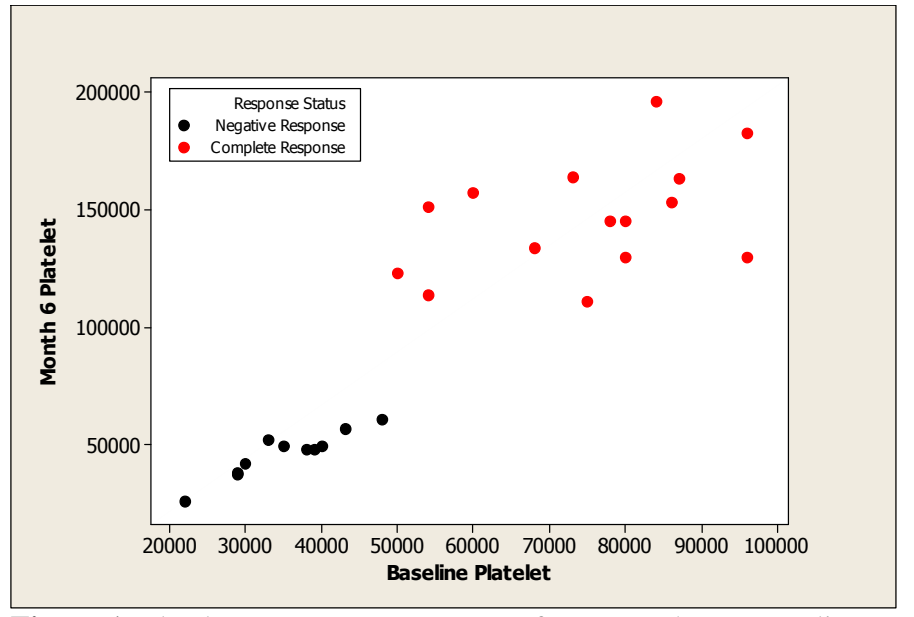

Figure 1. Platelet count response status after 6 months vs. Baseline Platelet. CR: Complete Response; NR: No Response

such as Japan and South Korea but this rate is in contrast studies were conducted in Western countries. ${ }^{3-}$
In general, the prevalence of H.pylori infection varies according to geographic location and in Asian countries such as Iran is too high..$^{3-5}$

In this study all patients with H.pylori infection were treated with triple therapy regimen and eradication rate was $86.5 \%$. This finding is in agreement to other studies which have showed successful eradication greater than $70 \%$ using triple therapy. ${ }^{17,18}$

In this study $65.6 \%$ of ITP patients had an increase of platelet counts after eradication of H.pylori infection. We found that there is a significantly association between overall response rate and eradication therapy infections $(p<0.001)$. According our data in other studies, conducted by Emilia et al, Fujimara $e t$ al and Inaba et al respectively 68\%, 63\% and $44 \%$ of ITP patients showed significant increase in platelet count after H.pylori eradication. ${ }^{16-18}$ In contrast 
the effects of eradication therapy had no favorable effect on platelet count in other series. Ahn et al reported increased platelet count only in $7 \%$ of treated patients $^{19}$, no platelet response were observed in ITP patients after eradication therapy of H.pylori infection in studies done by Micheal et al and Stasi et al. ${ }^{20,25}$ The discrepancy among these studies might be due to geographic variation in expression of some proteins such as Cag A (Cytotoxin-associated gene A) in different H.pylori genotypes. ${ }^{13,14}$ The prevalence of Cag A-positive H.pylori strains is different in geographical regions of the world. In Asian countries such as Japan, South Korea and Iran, most of H.pylori strains express $\mathrm{Cag} A ;^{26-28}$ whereas the frequency of Cag A positive H.pylori strain in Western countries is lower. ${ }^{29}$ Franceschi et $a l$ and Takahashi et al, documented association between H.pylori eradication with disappearance of anti Cag A antibodies and significant increase in platelet counts in ITP patients; they attributed the effect of HP eradication on platelet increase to HP Cag A molecular mimicry to platelet antigens. ${ }^{13,14}$

Thus, difference in the H.pylori genotypes and prevalence of Cag A positive H.pylori strains may explain variability in improvement of platelet counts after treatment in studies that were done in different geographic areas, but more work is needed to evaluate

\section{References:}

1. Correa P, Piazuelo MB. Natural history of Helicobacter pylori infection. Dig Liver Dis 2008; 40: 490-6. http://dx.doi.org/10.1016/j.dld.2008.02.035 $\quad$ PMid:18396115 PMCid:3142999

2. Menaker RJ, Sharaf AA, Jones NL. Helicobacter pylori infection and gastric cancer: host, bug, environment, or all three? Curr Gastroenterol Rep 2004; 6(6):429-35. http://dx.doi.org/10.1007/s11894-004-0063-9 PMid:15527671

3. Graham DY, Kimura K, Shimoyama T, Takemoto T. Helicobacter pylori infection in Japan: current status and future options. Eur J Gastroenterol Hepatol 1994; (6 Suppl 1):S1-4.

4. Yim JY, Kim N, Choi SH, Kim YS, Cho KR, Kim SS, Seo GS, Kim HU, Baik GH, Sin CS, Cho SH, Oh BH. Seroprevalence of Helicobacter pylori in South Korea. Helicobacter 2007; 12:333-40. http://dx.doi.org/10.1111/j.1523-5378.2007.00504.x PMid:17669107

5. Abadi AT, Taghvaei T, Mobarez AM, Carpenter BM, Merrell DS. Frequency of antibiotic resistance in Helicobacter pylori strains isolated from the northern population of Iran. J Microbiol 2011; 49(6):987-93. http://dx.doi.org/10.1007/s12275-011-1170-6 PMid:22203563 PMCid:3275342

6. Graham DY, Malaty HM, Evans DG, Evans DJ Jr, Klein PD, Adam E. Epidemiology of Helicobacter pylori in an asymptomatic population in the United States. Effect of age, race, and socioeconomic status. Gastroenterology 1991; 100:1495-501. PMid:2019355

7. Hershko C, Ianculovich M, Souroujon M. A hematologist's view of unexplained iron deficiency anemia in males: Impact of Helicobacter pylori eradication. Blood Cells Mol Dis 2007; 38(1):45-53. $\quad$ http://dx.doi.org/10.1016/j.bcmd.2006.09.006 PMid:17067833

8. Annibale B, Lahner E, Bordi C, Martino G, Caruana P, Grossi C, Negrini R, Delle Fave G. Role of Helicobacter pylori infection in pernicious anaemia. Dig Liver Dis 2000; 32(9):756-62. it formally.

In this study, all responders had platelet count $\geq 50 \times 10^{3} / \mu \mathrm{L}$ and we observed poor response to treatment in ITP patients with severe thrombocytopenia. Accordingly an other study, done by Stasi et al, $32 \%$ of patients with mild thrombocytopenia had a platelet response, but platelet response was observed only in one patient with severe thrombocytopenia. ${ }^{20}$ The reason of this situation has not been addressed in most reports, but these results show that the chance of obtaining a response by HP treatment is lower in patients with severe thrombocytopenia .

Conclusions. Results of this study revealed eradication therapy of H.pylori infection can improve platelet counts in ITP patients especially with mild thrombocytopenia. Also, our results show that H.pylori eradication cannot have a major role in the treatment of severe ITP patients. On the other hand; treating of H.pylori infection compared to conventional ITP treatment has some advantages such as the low cost, the non-invasiveness of diagnostic methods and favorable toxicity of drugs. Thus, this study supports routine detection and eradication of H.pylori infection in ITP patients in populations with a high prevalence of this infection such as Iran.

http://dx.doi.org/10.1016/S1590-8658(00)80351-5

9. Gasbarrini A, Franceschi F, Tartaglione R, Landolfi R, Pola P, Gasbarrini G. Regression of autoimmune thrombocytopenia after eradication of Helicobacter pylori. Lancet 1998; 352:878. http://dx.doi.org/10.1016/S0140-6736(05)60004-9

10. Hohmann AW, Booth K, Peters V, Gordon DL, Comacchio RM. Common epitope on HIV p24 and human platelets. Lancet 1993; 342:1274-5. http://dx.doi.org/10.1016/0140-6736(93)92363-X

11. Romero R, Kleinman RE. Thrombocytopenia associated with acute hepatitis B infection. Pediatrics 1993; 91:150-2. PMid:8416484

12. Nagamine T, Ohtuka T, Takehara K, Arai T, Takagi H, Mori M. Thrombocytopenia associated with hepatitis $\mathrm{C}$ viral infection. J Hepatol 1996; 24:135-40. http://dx.doi.org/10.1016/S0168$\underline{8278(96) 80021-3}$

13. Franceschi F, Christodoulides N, Kroll MH, Genta RM. Helicobacter pylori and idiopathic thrombocytopenic purpura. Ann Intern Med 2004; 140:766-7. PMid:15126268

14. Takahashi T, Yujiri T, Shinohara K, Inoue Y, Sato Y, Fujii Y, Okubo M, Zaitsu Y, Ariyoshi K, Nakamura Y, Nawata R, Oka Y, Shirai M, Tanizawa Y. Molecular mimicry by Helicobacter pylori CagA protein may be involved in the pathogenesis of $\mathrm{H}$ pyloriassociated chronic idiopathic thrombocytopenic purpura. $\mathrm{Br} \mathrm{J}$ Haematol 2004; 124:91-6. http://dx.doi.org/10.1046/j.13652141.2003.04735.x PMid:14675413

15. Tag HS, Lee HS, Jung SH, Kim BK, Kim SB, Lee A, Lee JS, Shin $\mathrm{SH}$, Kim YS. Effects of Helicobacter pylori eradication in patients with immune thrombocytopenic purpura. Korean J Hematol 2010; 45(2):127-32.

16. Emilia G, Luppi M, Zucchini P, Morselli M, Potenza L, Forghieri F, Volzone F, Jovic G, Leonardi G, Donelli A, Torelli G. Helicobacter pylori infection and chronic immune thrombocytopenic purpura: long-term results of bacterium eradication and association with bacterium virulence profiles. Blood 2007; 110:3833-41. http://dx.doi.org/10.1182/blood-2006- 


\section{2-063222 PMid:17652264}

17. Inaba T, Mizuno M, Take S, Suwaki K, Honda T, Kawai K, Fujita M, Tamura T, Yokota K, Oguma K, Okada H, Shiratori Y. Eradication of Helicobacter pylori increases platelet count in patients with idiopathic thrombocytopenic purpura in Japan. Eur J Clin Invest 2005; 35:214-219. http://dx.doi.org/10.1111/j.13652362.2005.01471.x PMid:15733077

18. Fujimura K, Kuwana M, Kurata Y, Imamura M, Harada H, Sakamaki H, Teramura M, Koda K, Nomura S, Sugihara S, Shimomura T, Fujimoto TT, Oyashiki K, Ikeda Y. Is eradication therapy useful as the first line of treatment in Helicobacter pylori positive idiopathic thrombocytopenic purpura? Analysis of 207 eradicated chronic ITP cases in Japan. Int J Hematol 2005; 81:162168. http://dx.doi.org/10.1532/IJH97.04146 PMid:15765787

19. Ahn ER, Tiede MP, Jy W, Bidot CJ, Fontana V, Ahn YS. Platelet activation in Helicobacter pylori-associated idiopathic thrombocytopenic purpura: eradication reduces platelet activation but seldom improves platelet counts. Acta Haematol 2006; 116:19_ 24. http://dx.doi.org/10.1159/000092343 PMid:16809885

20. Stasi R, Rossi Z, Stipa E, Amadori S, Newland AC, Provan D. Helicobacter pylori eradication in the management of patients with idiopathic thrombocytopenic purpura. Am J Med 2005; 118:414-9. http://dx.doi.org/10.1016/j.amjmed.2004.09.014 PMid:15808140

21. Rodeghiero F, Stasi R, Gernsheimer T, Michel M, Provan D, Arnold DM, Bussel JB, Cines DB, Chong BH, Cooper N, Godeau B, Lechner K, Mazzucconi MG, McMillan R, Sanz MA, Imbach P, Blanchette V, Kühne T, Ruggeri M, George JN. Standardization of terminology, definitions and outcome criteria in immune thrombocytopenic purpura of adults and children: report from an international working group. Blood 2009; 113(11):2386-93. http://dx,10.1182/blood-2008-07-162503

22. Jackson SC, Beck P, Buret AG, O'Connor PM, Meddings J, Pineo G, Poon MC. Long term platelet responses to Helicobacter pylori eradication in Canadian patients with immune thrombocytopenic purpura. Int J Hematol 2008; 88(2):212-8. http://dx.doi.org/10.1007/s12185-008-0138-8 PMid:18668306

23. Logan RP, Walker MM. ABC of the upper gastrointestinal tract:
Epidemiology and diagnosis of Helicobacter pylori infection. Bmj 2001; 323:920-922. http://dx.doi.org/10.1136/bmj.323.7318.920 PMid:11668141 PMCid:1121445

24. Malfertheiner P, Megraud F, O'Morain C, Bazzoli F, El-Omar E, Graham D, Hunt R, Rokkas T, Vakil N, Kuipers EJ. Current concepts in the management of Helicobacter pylori infection - The Maastricht III Consensus Report. Gut 2007; 56:772-81. http://dx.doi.org/10.1136/gut.2006.101634 PMid:17170018 PMCid:1954853

25. Michel M, Cooper N, Jean C, Frissora C, Bussel JB. Does Helicobacter pylorus initiate or perpetuate immune thrombocytopenic purpura? Blood 2004; 103:890-6. http://dx.doi.org/10.1182/blood-2003-03-0900 PMid:12920031

26. Kodama M, Kitadai Y, Ito M, Kai H, Masuda H, Tanaka S, Yoshihara M, Fujimura K, Chayama K. Immune response to CagA protein is associated with improved platelet count after Helicobacter pylori eradication in patients with idiopathic thrombocytopenic purpura. Helicobacter 2007; 12(1):36-42. http://dx.doi.org/10.1111/j.1523-5378.2007.00477.x PMid:17241299

27. Kim JW, Kim JG, Chae SL, Cha YJ, Park SM. High prevalence of multiple strain colonization of Helicobacter pylori in Korean patients: DNA diversity among clinical isolates from the gastric corpus, antrum and duodenum. Korean J Intern Med 2004; 19(1):19. PMid: 15053036

28. Molaei M, Foroughi F, Mashayekhi R, Haghazali M, Zojaji H, Jafari F, Dabiri H, Zali MR. CagA status and VacA subtypes of Helicobacter pylori in relation to histopathologic findings in Iranian population. Indian J Pathol Microbiol 2010; 53(1):24-7. http://dx.doi.org/10.4103/0377-4929.59178 PMid:20090217

29. Pérez-Pérez GI, Bhat N, Gaensbauer J, Fraser A, Taylor DN, Kuipers EJ, Zhang L, You WC, Blaser MJ. Country-specific constancy by age in $\mathrm{CagA}+$ proportion of Helicobacter pylori infections. Int J Cancer 1997; 72:453-456. http://dx.doi.org/10.1002/(SICI) $1097-$ $\underline{0215(19970729) 72: 3<453:: \text { AID-IJC13 }>3.0 . C O ; 2-D}$ 